\title{
Nutritive value of Tanzania grass for dairy cows under rotational grazing
}

\author{
Alberto Magno Fernandes ${ }^{1}$, Fermino Deresz ${ }^{2}$, Douglas Sampaio Henrique ${ }^{3,4}$, Fernando César \\ Ferraz Lopes ${ }^{2}$, Leonardo Siqueira Glória ${ }^{4}$
}

\author{
${ }^{1}$ Universidade Estadual do Norte Fluminense Darcy Ribeiro, Campos dos Goytacazes, RJ, Brasil. \\ ${ }^{2}$ Embrapa Gado de Leite, Juiz de Fora, MG, Brasil. \\ ${ }^{3}$ Universidade Tecnológica Federal do Paraná, Campus Dois Vizinhos, PR, Brasil. \\ ${ }^{4}$ Programa de Pós-graduação em Ciência Animal, Universidade Estadual do Norte Fluminense Darcy Campos dos Goytacazes, RJ, Brasil.
}

\begin{abstract}
A nutritional analysis of Tanzania grass (Megathyrsus maximus Jacquin cv. Tanzânia was conducted. Pasture was managed in a rotational grazing system with a 30-day resting period, three days of paddock occupation and two grazing cycles. Ten Holstein $\times$ Zebu crossbred cows were kept within a 2-ha area divided into 11 paddocks ha ${ }^{-1}$. Cows were fed $2 \mathrm{~kg}$ of corn meal daily and performance was evaluated by weighing the animals every 14 days and by recording milk production twice a day. Nutritional composition of the Tanzania grass was determined from forage (extrusa) samples collected by esophageal fistulae from two animals. The nutritive value of Tanzania grass was estimated according to a modification of the CNCPS evaluation model. Tanzania grass supplemented with $2 \mathrm{~kg}$ of corn meal supplied $33.2 \%$ more net energy for lactation than required by the animals to produce $13.7 \mathrm{~kg}$ of milk day ${ }^{-1}$. Nevertheless, the amount of metabolizable protein met the daily protein requirement of the animals. Although the model used in the study requires adjustments, Tanzania grass has the potential to produce milk in a rotational grazing system.
\end{abstract}

Key Words: animal performance, dairy cows, tropical pastures

\section{Introduction}

Tanzania grass (Megathyrsus maximus (Jacquin); Simon and Jacobs, 2003) is a good alternative for milk production grazing systems due to its high nutritive value compared with its tropical counterparts (Chambela Neto et al., 2008). Tropical forages produce large amounts of dry matter per area and, consequently, support high stocking rates (Mott, 1960; Hodgson et al., 1981). In addition to high grass production, the efficiency of forage conversion into animal products depends on two factors. First, the quantity of nutrients ingested must be sufficient to meet the animal requirements for a specific production level. Second, enough material must be left after grazing to allow for vigorous regrowth and maintenance of the pasture, without compromising animal performance (Hodgson, 1985; Wilson and Mertens, 1995; Fisher et al., 1996; Lemaire and Chapman, 1996; Buxton and Redfearn, 1997; Gomide and Gomide, 2001; Nelson, 2011).

The knowledge accumulated over the last 100 years regarding the interactions between feed nutritional quality and the efficiency of feed utilization by animals justified

Received February 5, 2014 and accepted June 8, 2014.

Corresponding author: alberto@uenf.br

http://dx.doi.org/10.1590/S1516-35982014000800003

Copyright (C) 2014 Sociedade Brasileira de Zootecnia. This is an Open Access article distributed under the terms of the Creative Commons Attribution Non-Commercial License, which permits unrestricted non-commercial use, distribution, and reproduction in any medium, provided the original work is properly cited. the development of animal-performance evaluation systems based on feed intake and nutrient composition (Fox et al., 2004). Recently, mathematical models for diet formulation using non-linear optimization techniques have been suggested by several authors (Souza, 2006; Tedeschi et al., 2008; Jardim et al., 2013). These models allow for simultaneous diet formulation and evaluation to meet animal protein, energy, and fiber requirements, subject to the constraint of maximum fiber intake capacity (Favoreto et al., 2008; Jardim et al., 2013). However, these models need to be repeatedly evaluated and updated to enhance predictive and optimization powers.

The objective of this study was to estimate the nutritive value of Tanzania grass for lactating Holstein $\times$ Zebu crossbred cows under rotational grazing, using a non-linear model that accounts for the interactions between dietary components and the digestion and metabolism of these components by the animal.

\section{Material and Methods}

The experiment was conducted from January to April 2009 in the Zona da Mata Region of Minas Gerais. The experimental area has an average altitude of $435 \mathrm{~m}$, and a Cwa climate according to the Köppen classification.

The experimental area included eleven $910-\mathrm{m}^{2}$ paddocks divided by electric fences and planted with Tanzania grass 
(Megathyrsus maximus Jacquin cv. Tanzania (Simon and Jacobs, 2003)) in 2007. The pasture was fertilized with $\mathrm{N}$ and $\mathrm{K}_{2} \mathrm{O}\left(220 \mathrm{~kg} \mathrm{ha}^{-1}\right.$ year $^{-1}$ each), and with $55 \mathrm{~kg} \mathrm{ha}^{-1}$ year $^{-1}$ of $\mathrm{P}_{2} \mathrm{O}_{5}$. The fertilizer was applied when animals left the paddocks. Paddocks were managed on a schedule of threeday occupation with thirty-day rest intervals. Ten Holstein $\times$ Zebu crossbred cows (60 days of lactation) with an average body weight of $495 \mathrm{~kg}$ and an average body condition score of 2.8 were used, resulting in a stocking rate of 5.3 animal units (AU) per hectare. Whenever necessary, dry cows were used to maintain a grazing balance of $0.3-\mathrm{m}$ post-grazing residual height in each grazing cycle. Animal performance was evaluated by recording milk production of the cows at $06.00 \mathrm{~h}$ and $13.00 \mathrm{~h}$ daily and by weighing cows every 14 days. The concentrate feed ( $2 \mathrm{~kg}$ of corn meal) was split into two meals and offered during milkings. Mineral salt and water were available to the animals ad libitum. Milk samples from each cow were collected for determination of crude protein, fat, lactose, total solids, and non-fat total solids.

During the three-day grazing period, extrusa was collected from two half-bred, non-lactating cows via esophageal fistulae equipped with collecting bags of synthetic canvas with netted bottoms, adjusted below the fistula for saliva drainage (Bishop and Froseth, 1970). Fistulated animals were subjected to 12 hours of fasting before each collection to avoid contamination by regurgitated material. The sampling period in each paddock was approximately 30 minutes. Samples were stored in plastic bags and frozen $\left(-20^{\circ} \mathrm{C}\right)$ until the end of the field experiment.

Extrusa samples were analyzed for dry matter (DM), ash (MM), ether extract (EE), and crude protein (CP) according to AOAC (1990) and for neutral detergent fiber (NDF), lignin, and neutral detergent fiber corrected for protein and ash (NDFap) according to Goering and Van Soest (1970). Non-fibrous carbohydrates (NFC), fibrous carbohydrates (FC), and indigestible carbohydrates (C' fraction) were analyzed according to Sniffen et al. (1992). Neutral detergent insoluble fibrous carbohydrates $\left(\mathrm{B}_{2}\right.$, fraction) was calculated as fraction $\mathrm{C}^{\prime}$ subtracted from total FC. Fractions A' (simple sugars) and $\mathrm{B}_{1}$ ' (non-fibrous complex carbohydrates) were estimated by in vitro gravimetric and gas production techniques. A gravimetric profile of degradation of neutral detergent fiber corrected for ash and protein (NDFap) was obtained after incubation of samples (Favoreto et al., 2008).

Protein fractions were determined as follows: fraction A (non-protein nitrogen) as the difference between total $\mathrm{N}$ and $\mathrm{N}$ insoluble in trichloroacetic acid; fraction $\mathrm{C}$ as the acid detergent insoluble protein (ADICP) that is indigestible in the gastrointestinal tract of the animal; fraction $\mathrm{B}_{2}$ (protein with a slow degradation rate) as the difference between neutral detergent insoluble protein (NDICP) and ADICP according to Sniffen et al. (1992); and fraction $\mathrm{B}_{1}$ (protein with a faster degradation rate than fraction $\mathrm{B}_{2}$ ) by the difference, according to the equation $100-\left(\mathrm{A}+\mathrm{B}_{2}+\mathrm{C}\right)$ (Favoreto et al., 2008).

Feces samples were collected directly from the rectum of lactating cows and frozen $\left(-20^{\circ} \mathrm{C}\right)$ in plastic bags. After sampling, feces were pre-dried in a forced air oven $\left(55^{\circ} \mathrm{C}\right.$ for 72 hours), processed and ground in a Wiley-type mill to pass through a 1-mm sieve, and stored in glass flasks at room temperature until chemical composition determination.

Dry matter intake (DMI) was estimated using animal fecal production data; and indigestibility of forage was based on the estimated NDF indigested residual from forage as the asymptotic indigestible residue $\left(U_{p}\right.$; Eq. 1). Fecal production was determined with chromium oxide $\left(10 \mathrm{~g} \mathrm{cow}^{-1} \mathrm{~d}^{-1}\right)$, with $5 \mathrm{~g}$ administered orally twice per day, over 16 days. The first ten days established the marker excretion; over the last six days, feces were collected directly from the rectal ampoule. Feces samples were stored in plastic bags at $-20{ }^{\circ} \mathrm{C}$. After the sampling period, feces were dried in a laboratory oven at $55^{\circ} \mathrm{C}$ for 72 hours until the determination of chromium concentration.

The food matter dynamics were estimated based on in vitro gravimetric techniques, cumulative gas production from microbial fermentation, and determination of transit kinetics (particles and liquid phase) through the gastrointestinal tract. In vitro degradation of fiber was measured by heat incubation $\left(39{ }^{\circ} \mathrm{C}\right)$ of samples in duplicate. At each incubation time $(0,1,3,6,9,12,24,36$, 72 and 96 hours), samples were ground to $1 \mathrm{~mm}$ and added to tubes with buffer solution and ruminal inocula; and the residual content of NDF corrected for ash and protein (NDFap) was determined at each incubation time (Goering and Van Soest, 1970). The fiber degradation kinetics was interpreted by the decreasing sigmoid model proposed by Vieira et al. (2008a):

$R(t)=A_{p}\left\{\delta_{a}^{N_{a}} \exp \left(-k_{d 3} t\right)+v \exp \left(-\lambda_{a} t\right) \sum_{i=0}^{N_{a}-1}\left[\frac{\left(1-\delta_{a}^{N_{a}-i}\right)\left(\lambda_{a} t\right)^{i}}{i !}\right]\right\}+U_{p}+\varepsilon$

In the model, $R(t)\left(\mathrm{g} \mathrm{g}^{-1}\right)$ is the incubation residue after in vitro incubation for a given period of time $t(\mathrm{~h}) ; A_{p}\left(\mathrm{~g} \mathrm{~g} \mathrm{~g}^{-1}\right)$ represents the potentially degradable fiber not available for digestion at time zero; $N_{a}$ (dimensionless) is the order of time dependency (positive integer) related to the preparation of the fraction $A_{p}$ for digestion; $k_{d 3}{ }^{\prime}\left(\mathrm{h}^{-1}\right)$ corresponds to the fiber degradation rate; $\lambda_{a}\left(\mathrm{~h}^{-1}\right)$ is the fiber availability rate of $A_{p}$ as a function of time (dynamic lag); parameter $U_{p}$

R. Bras. Zootec., 43(8):410-418, 2014 
$\left(\mathrm{g} \mathrm{g}^{-1}\right)$ is the asymptote of the function when $t$ tends to infinite, equivalent by definition to the indigestible fraction of the nutrient being studied; and $\varepsilon$ refers to random error, with an assumed normal and independent distribution.

The following equation (Vieira et al., 2008b) was used to estimate the effective ruminal degradability (DE) of fiber:

$D E=B_{2}^{\prime} k_{d 3^{3}}\left\{\sum_{i=1}^{N}\left[\lambda_{r}^{i-1} /\left(\lambda_{r}+k_{d 3^{\prime}}\right)^{i}\right]+\lambda_{r}^{N} /\left[\left(\lambda_{r}+k_{d 3^{\prime}}\right)^{N}\left(k_{e}+k_{d 3^{\prime}}\right)\right]\right\}$

In which $B_{2}^{\prime}\left(\mathrm{g} \mathrm{g}^{-1}\right)$ is equal to the potentially degradable fiber; $\lambda_{r}\left(\mathrm{~h}^{-1}\right)$ represents the transfer rate of particles to the potential escape zone; $N$ is the dependence order (positive integer) of the particle transfer to the potential escape zone; and $k_{e}\left(\mathrm{~h}^{-1}\right)$ is the passage rate of particles in the potential escape zone. The other terms were previously described.

Kinetic parameters of NFC and $B_{2}^{\prime}$ fractions were estimated by the gas production technique. Cumulative gas production by fermentation was obtained after in vitro anaerobic incubations in a water bath at $39{ }^{\circ} \mathrm{C}$, based on methodologies described by Malafaia et al. (1999). Incubations were conducted in glass flasks $(100 \mathrm{~mL})$ with butyl rubber stoppers and aluminum seals containing $75 \mathrm{~mL}$ of culture medium, $5 \mathrm{~mL}$ of ruminal inocula and approximately $250 \mathrm{mg}$ of DM. Gas volume was measured at $0,1,3,6,9,12,24,48,72$ and 96 hours.

After acquiring the gas production profile from the extrusa dry matter, the final gas volume was estimated by adjusting the model:

$$
V_{(t)}=V_{f}(1-\exp (-c t))+\varepsilon
$$

In this model, $V(t)$ corresponds to the accumulated volume of gas at time $t$, expressed in $\mathrm{mL} ; V_{f}$ is equal to the maximum volume produced; and $\mathrm{c}$ represents the availability of substrate for digestion and its degradation rate, expressed in $\mathrm{h}^{-1}$.

The contributions of the FC and NFC (CT - FC) to the final gas production $\left(V_{f}\right)$ were predicted based on the assumption that the volume of gas produced per monomeric unit of carbohydrate assimilated and fermented by microbial mass is the same for fibrous and non-fibrous carbohydrates (Beuvink et al., 1992; Schofield et al., 1995). The following equations were used:

$$
\begin{gathered}
V_{N F C}(t)=V_{f N F C}\left[1-\exp \left(-k_{d 1}, t\right)\right]+\varepsilon \\
V_{F C}(t)=V_{F C}\left[1-\left\{\delta_{\mathrm{a}}^{N a} \exp \left(-k_{d 3^{\prime}} t\right)+\exp \left(-\lambda_{a} t\right) \sum_{i=0}^{N a-1}\right.\right. \\
\left.\left[\left(1-\delta_{\mathrm{a}}^{N_{a}-i}\right)\left(\lambda_{a} t\right)^{i} / i !\right]\right\}
\end{gathered}
$$

In which $V_{F C}(t)(\mathrm{mL})$ represents the volume of gas produced from fibrous carbohydrates; $V_{N F C}(t)(\mathrm{mL})$ represents the volume of gas from non-fibrous carbohydrate fermentation; and $V_{f N F C}(t)(\mathrm{mL})$ represents the final volume of gas estimated from non-fibrous carbohydrates.

Mordant fiber for determination of solid phase rate of passage was obtained from the extrusa samples (Udén et al., 1980) treated with $20 \mathrm{mg}$ chromium $\mathrm{g}^{-1} \mathrm{NDF}$. Three hundred grams of fiber treated with dichromate were offered to the animals in one dose during the morning milking. The rate of passage of fluids was determined using Co-EDTA (Udén et al., 1980). Five grams of Co-EDTA (with a concentration of $12.0 \%$, determined in laboratory) packed paper cylinders were supplied orally to the animals. A total of 28 feces samples were collected at times $0,1,2,4,6,8,10,12,16$, $20,24,28,32,36,40,44,48,56,64,72,80,88,96,108,120$, 132,144 and $192 \mathrm{~h}$ after mordant fiber administration. After collection and processing of feces (drying and milling), the levels of chromium and cobalt were determined by atomic absorption spectrometry.

The kinetic parameters of passage were estimated by adjusting the model to the indicator excretion profiles of the two-compartment generalized exponential model proposed by Pond et al. (1988), using the statistical program SAS (Statistical Analysis System, version 9). The parameters of passage rate were estimated by the GnG1 models, considering the Gamma probability density function over time $\Gamma\left(N, \lambda_{r}, t\right)$, according to Matis (1972), Pond et al. (1988), and Matis et al. (1989), $N$ varying from 1 to 4 .

$$
\begin{gathered}
C(t)=\varepsilon, \quad 0 \leq t \leq \tau \\
C(t)=C(0) k_{e} \cdot\left\{\delta^{N} \exp \left[-k_{e}(t-\tau)\right]-\exp \left[-\lambda_{r}(t-\tau)\right] \cdot \sum_{i=1}^{N} \frac{\delta^{i} \cdot\left[\lambda_{r}(t-\tau)^{N-i}\right.}{(N-1) !}\right\} \\
+\varepsilon t \geq \tau
\end{gathered}
$$

In which the $\delta=\lambda_{r} /\left(\lambda_{r}-k_{e}\right)$ ratio was used to simplify the equation, and the model parameters were dependent on the restriction, $k_{e}<\lambda_{r}$. $C$ is the fecal concentration of the indicator; $C(0)$ is the concentration of the indicator in the retention compartment at time zero; and $\tau$ is the transit time of particles through the gastrointestinal tract (discrete latency). The fluid passage rate was determined by fitting Eq. (6) and (7) to the excretion profiles of Cobalt and by assuming $\mathrm{N}=1$ and $k_{e}=\mathrm{k}_{\mathrm{l}}$.

Average ruminal retention time (RRT) was determined by the following expression:

$$
R R T=\frac{N}{k_{e}}+\frac{1}{\lambda_{r}}
$$

The nutritive value of Tanzania grass was estimated according to the CNCPS (Fox et al., 2004) with the following modifications: the requirements of total net energy $\left(\mathrm{NE}_{\mathrm{t}}\right)$ and total metabolizable protein $\left(\mathrm{MP}_{\mathrm{t}}\right)$ were determined using the equations described in NRC (2001), and the mathematical structures of the CNCPS and NRC 
models were modified to accommodate four fractions of nitrogen compounds, according to Souza (2006). Relevant modifications were made based on the models of Vieira et al. (2008a,b), such as the calculation of effective ruminal degradability of protein and carbohydrate fractions and the prediction of fiber mass from the rumen-reticulum. The system of equations was programmed on Microsoft Excel ${ }^{\mathbb{R}}$ 2007 and the observed DMI, milk production, nutritional composition of feed data as well as feed degradation and passage rates through the gastrointestinal tract were included as inputs for the calculation of $\mathrm{NE}_{\mathrm{t}}$ and $\mathrm{MP}_{\mathrm{t}}$ requirements and intake. The intakes of NEt and MPt were compared with their required counterparts to verify the consistency of the model outputs. The predictive power of the system was evaluated by the comparison between the predicted and observed values of DMI and milk production as well as the requirements of net energy $\left(\mathrm{NE}_{\mathrm{L}}\right)$ and metabolizable protein $\left(\mathrm{MP}_{\mathrm{L}}\right)$ for lactation. Dry matter intake was predicted using the observed production data, whereas milk production was predicted using the observed DMI as an input to the model. Observed $\mathrm{NE}_{\mathrm{L}}$ and $\mathrm{MP}_{\mathrm{L}}$ were determined from the milk composition and production of each cow; the predicted $\mathrm{NE}_{\mathrm{L}}$ and $\mathrm{MP}_{\mathrm{L}}$ values were calculated by the system. The predictive capacity of the model was evaluated with Model Evaluation System (MES) according to methodology described by Tedeschi (2006).

\section{Results and Discussion}

The levels of fiber (Table 1) observed in extrusa were similar to the results reported by Barbosa and Euclides (1997) in a study on the nutritive value of three ecotypes of Megathyrsus, including Tanzania grass. Those authors obtained average fiber levels of $72.9 \%$ of DM.

The concentration of crude protein (Table 1) in Tanzania grass in the two periods was higher than the $121 \mathrm{~g} \mathrm{~kg}^{-1}$ of DM reported by Lima et al. (2001) when extrusa of this same forage was fertilized with $150 \mathrm{~kg} \mathrm{ha}^{-1}$ year $^{-1}$ of nitrogen and managed in rotational grazing. That difference can be explained by the management of the present experiment, which allowed the animals to graze plants with a lower regrowth age, confirming that a higher physiological age of plants corresponds to higher levels of structural cellwall components and lower nutritional quality (Van Soest, 1994). The values of DM observed in the present work do not differ from those reported in the literature (Gerdes et al., 2000; Lima et al., 2001).

Russell et al. (1992) described the importance of accurate determination of nitrogen fractions and their respective digestion rates to formulating diets that maximize the utilization efficiency of $\mathrm{N}$ by rumen microbes and by the host. The non-protein nitrogen proportion (fraction A) observed in the present study (Table 2) was lower than the levels of 18 to $28 \mathrm{~g} / 100 \mathrm{~g}$ described by Balsalobre et al. (2003) from a study on Tanzania grass nitrogen fractions under a simulated-grazing treatment.

Nitrogen fraction $\mathrm{B}_{2}$ (Table 2) corresponds to fraction $\mathrm{B}_{3}$ of the fractionation proposed by Sniffen et al. (1992) and is below the values observed by Balsalobre et al. (2003) and by Silva et al. (2009), who found that fraction $\mathrm{B}_{3}$ varied from 41.7 to $32.2 \mathrm{~g} / 100 \mathrm{~g}$ at $0.20 \mathrm{~m}$ height and from 44.5 to $30.8 \mathrm{~g} / 100 \mathrm{~g}$ at $0.40 \mathrm{~m}$ height. Similar values $(26.9 \mathrm{~g} / 100 \mathrm{~g})$ were observed by Malafaia et al. (1999) for Tifton 85 cut at approximately 60 days of age. This fraction is slowly degraded in the rumen and is therefore an important source of amino acids to the small intestine (Sniffen et al., 1992).

Clipes et al. (2006), working with extrusa samples of Mombaça grass (Panicum maximum cv. Mombaça) pastures managed with three-day occupation periods and 36-day resting periods, reported values of 4.4 and $32.8 \mathrm{~g} / 100 \mathrm{~g}$ for nitrogen fractions $\mathrm{B}_{1}$ and $\mathrm{B}_{2}$, respectively, on the first day of occupation, and values of 8.2 and $33.3 \mathrm{~g} / 100 \mathrm{~g}$, respectively, on the third day of occupation. In the present study, the value of fraction $B_{1}$, which is equivalent to the sum of fractions $B_{1}$ and $B_{2}$ of the Sniffen et al. (1992) fractionation, was $56.31 \mathrm{~g} / 100 \mathrm{~g}$ of CP. Low concentrations of fractions $\mathrm{B}_{1}$ and $\mathrm{B}_{2}$ can decrease the availability of amino acids and peptides for the non-structural carbohydrate fermenters in the rumen and impede the supply of potentially digestible protein to the small intestine (Waters et al., 1992).

Fraction C, which represents the proportion of unavailable protein not digested in the rumen and intestines (Van Soest, 1994), may vary from 5 to $15 \mathrm{~g} / 100 \mathrm{~g}$ of total $\mathrm{N}$. These values were lower than the values for Tanzania grass

Table 1 - Chemical composition of the consumed forage (extrusa) and of the ground corn

\begin{tabular}{lccc}
\hline & \multicolumn{2}{c}{ Feed $\left(\mathrm{g} \mathrm{kg}^{-1}\right.$ of dry matter) } \\
\cline { 2 - 3 } Chemicalcomposition & Tanzania grass (Extrusa samples) & \multirow{2}{*}{ Corn } \\
\cline { 2 - 3 } & Period 1 & Period 2 & \\
\hline Dry matter $^{1}$ & 755 & 156 & 901 \\
Ash & 139 & 81 & 16 \\
Crude protein & 25 & 171 & 99 \\
Crude fat & 735 & 28 & 42 \\
Neutral detergent fiber & 52 & 711 & 95 \\
Lignin & 117 & 35 & - \\
NDICP & 100 & 147 & 90 \\
ADICP & 758 & 90 & 10 \\
Total carbohydrates & 163 & 720 & 843 \\
Non-fibrous carbohydrates & 595 & 197 & - \\
Fibrous carbohydrates & & 523 & - \\
\hline
\end{tabular}

${ }^{1}$ Percentage of fresh matter.

NDICP - neutral detergent insoluble crude protein; ADICP - acid detergent insoluble crude protein. 
shown in Table 2, which may result in a lower microbial efficiency.

The concentration of rapidly degradable carbohydrates (solublecarbohydrates, starchandnon-starchpolysaccharides that constitute fractions $\mathrm{A}^{\prime}$ and $\mathrm{B}_{1}{ }^{\text {') }}$ were similar (Table 3) to the $15.38 \mathrm{~g} / 100 \mathrm{~g}$ for fractions $\mathrm{A}^{\prime}+\mathrm{B}_{1}$ ' published by Balsalobre et al. (2003). According to Vieira et al. (2000), tropical grasses rarely have levels of soluble carbohydrates and starch higher than $20 \%$ of total carbohydrates. The same authors observed $\mathrm{A}^{\prime}$ and $\mathrm{B}_{1}{ }^{\prime}$ concentrations of 13.6 and 1.57 $\mathrm{g} / 100 \mathrm{~g}$, respectively, in extrusa from natural pastures in the Zona da Mata Region (MG, Brazil) during the rainy season. The beneficial effects of sugars (fraction A') on the animals are related to the following factors: fast microbial growth caused by readily available energy and higher microbial utilization efficiency of soluble and non-protein nitrogen. Fraction $\mathrm{B}_{1}$, is an intermediately available energy source for the microbiota (slower than soluble carbohydrates and faster than fibrous carbohydrates); improved $\mathrm{B}_{1}$ ' utilization will depend on synchronization of nitrogen availability in the rumen to maximize the production of microbial protein (Sniffen et al., 1992).

The results obtained for the levels of fraction C' (Table 3) did not differ from the values normally observed in tropical grasses. Favoreto et al. (2008) observed levels of $20.37 \mathrm{~g} / 100 \mathrm{~g}$ in star grass (Cynodon nlemfuensis). Vieira et al. (2000) highlighted the importance of determining this fraction, as it is considered to be unavailable in the rumen and the intestines. The same authors concluded that the increase in fraction C' occurs to the detriment of fraction $\mathrm{B}_{2}$, increasing the rumen fill effect and decreasing the energy available to the rumen microorganisms.

Potentially degradable structural carbohydrates (fraction $\mathrm{B}_{2}{ }^{\prime}$ ) are the main source of energy for grazing animals. Levels of this fraction in Tanzania grass were 58.04 to $63.66 \mathrm{~g} / 100 \mathrm{~g}$ of TC.

An asymptotic first-order model adjusted to gas production data from DM and FC allowed for the

Table 2 - Protein fractions ${ }^{1}$ and their degradation rates $^{2}$

\begin{tabular}{lcccc}
\hline \multirow{2}{*}{ Item } & & \multicolumn{2}{c}{ Tanzania grass } & \multirow{2}{*}{ Corn meal } \\
\cline { 2 - 4 } & & Period 1 & Period 2 & \\
\hline \multirow{2}{*}{ Fractions $\left(\mathrm{g} \mathrm{kg}^{-1}\right.$ of } & $\mathrm{A} 1$ & 563.1 & 563.1 & 120.7 \\
crude protein) & $\mathrm{B} 2$ & 245.9 & 245.9 & 75.3 \\
& $\mathrm{C}$ & 165.6 & 165.6 & 15.1 \\
Degradation rates $\left(\mathrm{h}^{-1}\right)$ & $\mathrm{kd}_{1}$ & $1.67^{3}$ & $1.67^{3}$ & $0.26^{3}$ \\
& $\mathrm{kd}_{2}$ & $0.07^{3}$ & $0.07^{3}$ & $0.02^{3}$ \\
\hline
\end{tabular}

${ }^{1} \mathrm{~A}$ - non-protein nitrogen; B1 - neutral detergent soluble true protein; B2 - potentially degradable true neutral detergent insoluble protein; $\mathrm{C}$ - unavailable neutral detergent insoluble true protein.

${ }^{2} \mathrm{kd}$ for $\mathrm{B} 1$ and $\mathrm{kd}_{2}$ for $\mathrm{B} 2$.

${ }^{3}$ Values obtained from tables of CNCPS. determination of the NFC gas production curve (Figure 1). The $\mathrm{V}_{\mathrm{f}}$ of $\mathrm{FC}$ was $12.3 \mathrm{~mL} / 100 \mathrm{mg} \mathrm{DM}$, and the $\mathrm{V}_{\mathrm{f}}$ of $\mathrm{NFC}$ was $2.2 \mathrm{~mL} / 100 \mathrm{mg}$ DM.

Fractions $\mathrm{A}^{\prime}$ and $\mathrm{B}_{1}{ }^{\prime}$ could not be differentiated in this study, despite the possibility of determining those fractions with in vitro assays of gravimetric fiber degradation and cumulative gas production. Chemical determination of fractions $\mathrm{A}^{\prime}$ and $\mathrm{B}_{1}{ }^{\prime}$ is very laborious due to the physicochemical properties of the large diversity of substances of which they are comprised (Van Soest et al., 1991). Therefore, the gasogenic contribution was estimated from NFC (considered to represent the sum of fractions $\mathrm{A}^{\prime}$ and $\left.\mathrm{B}_{1}{ }^{\prime}\right)$, and the two fractions were estimated by the mathematical procedures of Favoreto et al. (2008). CNCPS defines four fractions of carbohydrates according to their degradation rate in the rumen. These fractions are determined by chemical analysis (Sniffen et al., 1992);

Table 3 - Carbohydrate fractions ${ }^{1}$ of Tanzania grass (extrusa) and ground corn and their degradation rates ${ }^{2}$

\begin{tabular}{lcccc}
\hline \multirow{2}{*}{ Item } & & \multicolumn{2}{c}{ Tanzania grass } & \multirow{2}{*}{ Corn } \\
\cline { 3 - 4 } & & Period 1 & Period 2 & \\
\hline \multirow{3}{*}{ Fractions (\% of } & $\mathrm{A}^{\prime}$ & 19.78 & 16.28 & 8.94 \\
total carbohydrate) & $\mathrm{B}{ }^{\prime}$, & 0.82 & 0.68 & 79.86 \\
& $\mathrm{~B}{ }^{\prime}$, & 58.04 & 63.66 & 10.66 \\
& $\mathrm{C}^{\prime}$ & 21.36 & 19.38 & 0.57 \\
Degradation rates $\left(\mathrm{h}^{-1}\right)$ & $\mathrm{kd}_{1}{ }^{\prime}$, & 0.46 & 0.46 & $0.35^{3}$ \\
& $\mathrm{kd}_{3}{ }^{\prime}$ & 0.08 & 0.08 & $0.06^{3}$ \\
\hline
\end{tabular}

${ }^{1}$ A' - soluble sugars; B1' - neutral detergent soluble complex carbohydrates; B2' degradable fibrous carbohydrates; C' - unavailable fibrous carbohydrates and lignin

${ }^{2} \mathrm{kd}_{1}{ }^{\prime}=\mathrm{kd}_{2}$ ' for the pooled $\mathrm{A}^{\prime}+\mathrm{B} 1$ '; and $\mathrm{kd}_{2}$ ' for $\mathrm{B} 2$ '

${ }^{3}$ Values obtained from tables of CNCPS.
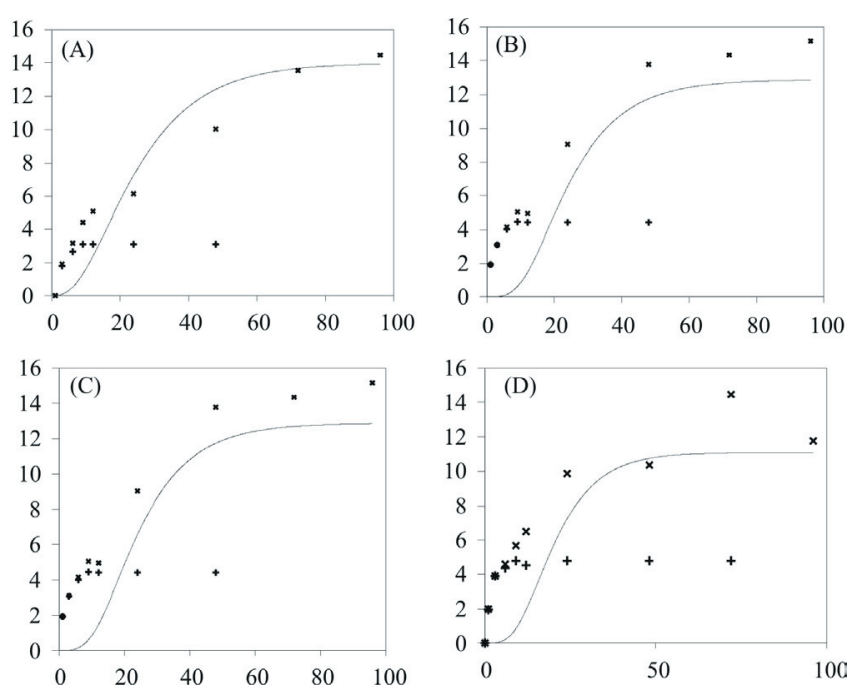

The continuous line represents the gas production simulated for fibrous carbohydrates and the observed gas volumes presented are from DM $(\times)$ and non-fibrous carbohydrates $(+)$.

Figure 1 - Gas production curves for period 1 (panels A and B) and period 2 (panels C and D). 
however, each fermented substrate cannot be chemically determined with the gas production analysis; only large groups of compounds with similar degradation rates can be identified. Gas production analysis detects only the combined fraction of NFC ( $\left.\mathrm{A}^{\prime}+\mathrm{B} 1^{\prime}\right)$, which has a higher degradation rate than that of $\mathrm{FC}\left(\mathrm{B} 2^{\prime}\right)$. The separation of these fractions into distinct pools is only possible when fermentation pattern and microbial growth are the only factors considered. These results corroborate the theory of Lucas and Smart (1959), which states that if a fraction of the food has uniform nutritional behavior, then subfractions that compose it will behave similarly.

The solid-phase passage rates observed in the literature are generally between 0.02 and $0.08 \mathrm{~h}^{-1}$ (AFRC, 1993); similar values were published by Lopes (2002) for lactating Gir or crossbred Holstein $\times$ Zebu cows grazing on tropical forages (Table 4).

Microbial degradation of cell-wall constituents in the rumen is a relatively slow process. Ruminants have evolved the ability to retain solid particles of food in the rumen for a longer time than fluids, allowing for more efficient microbial utilization of cell wall constituents (Van Soest, 1994). However, longer retention times may constrain voluntary intake due to the rumen-fill effect (Lechner-Doll et al., 1991). The mean retention times of solids and liquids were 25.2 and $10.7 \mathrm{~h}$, respectively, in the present study. The greater the voluntary feed intake, the lower is the mean residence time of fibrous particles and the lower the metabolizability of the diet (Van Soest, 1994;

Table 4 - Estimates of passage parameters of the particulate and fluid phases in the rumen

\begin{tabular}{lccc}
\hline \multirow{2}{*}{ Parameters } & \multicolumn{3}{c}{ Statistics } \\
\cline { 2 - 4 } & Mean & SE & CV\% \\
\hline$\lambda_{r}\left(\mathrm{~h}^{-1}\right)$ & 0.3533 & 0.2354 & 66.63 \\
$k_{e}\left(\mathrm{~h}^{-1}\right)$ & 0.0626 & 0.0212 & 33.94 \\
$k_{l}\left(\mathrm{~h}^{-1}\right)$ & 0.0959 & 0.0161 & 16.77 \\
SMRT $(\mathrm{h})$ & 25.2 & 5.5 & 21.8 \\
LMRT(h) & 10.7 & 1.6 & 14.96
\end{tabular}

$\mathrm{SE}$ - standard error; CV - coefficient of variation.

$\lambda$ - passage rate of the particles from the raft; $k_{e}$ - passage rate of particles from the escapable pool of the rumen; $k_{l}$ - fluid passage rate; SMRT - mean retention time of solids in the rumen; LMRT - mean retention time of liquids in the rumen.
AFRC, 1993). Nevertheless, despite a greater feed intake, it is possible to maintain the metabolizability of the diet constant irrespective of the plane of nutrition by means of nonlinear optimization techniques (Jardim et al., 2013).

The average milk production was $13.7 \pm 2.5 \mathrm{~kg} \mathrm{~d}^{-1}$, with fat and protein concentrations of 38 and $30 \mathrm{~g} \mathrm{~kg}^{-1}$, respectively; the predicted production was $15.6 \pm 3.6 \mathrm{~kg} \mathrm{~d}^{-1}$. The results of Mean Bias (MB) indicated that the predicted values were close to those observed; however, the predicted values were systematically overestimated (Table 5). After a Cochran and Cox (1954) test was conducted with the MB values, the DM intake (Table 5) and milk production estimates were not significantly different from zero, demonstrating the accuracy of the model in predicting those variables.

The agreement correlation coefficients that describe how close data are to the 1:1 line, and the intraclass correlation coefficient did not support rejection of the respective null hypotheses (Table 5), indicating the low precision of the model predicting milk production, $\mathrm{DM}$ intake, $\mathrm{MP}_{\mathrm{L}}$ and $\mathrm{NE}_{\mathrm{L}}$ requirements. The model should present accuracy and precision for a perfect adjustment (Tedeschi et al., 2004). Both characteristics are measured independently; therefore, a precise method does not guarantee accuracy and vice-versa.

Mean bias indicated an overestimation of the metabolizable protein requirement for lactation $\left(\mathrm{MP}_{\mathrm{L}}\right)$ by the model. However, the accuracy for this variable was reasonable, indicating that the performance of the model was satisfactory, justifying its use (Tedeschi, 2006).

The predicted milk production was calculated using the first limiting nutrient as a restriction. When the ratio between $\mathrm{NE}_{\mathrm{t}}$ intake and $\mathrm{NE}_{\mathrm{t}}$ requirement was lower than the $\mathrm{MP}_{\mathrm{t}}$ ratio (according to the same calculation), $\mathrm{NE}_{\mathrm{t}}$ was considered the first limiting nutrient, and vice versa. This procedure enhanced the accuracy of the model predictions of milk production (Table 5). However, when $\mathrm{MP}_{\mathrm{L}}$ and $\mathrm{NE}_{\mathrm{L}}$ predictions were analyzed independently, the systematic error of the model increased, and the accuracy decreased, more significantly for $\mathrm{NE}_{\mathrm{L}}$ than for $\mathrm{MP}_{\mathrm{L}}$. This effect is demonstrated by the $\mathrm{P}$-values of the MB for milk production, $\mathrm{NE}_{\mathrm{L}}$ and $\mathrm{PM}_{\mathrm{L}}$ (Table 5). The $\mathrm{MB}$ value of DMI prediction was near zero, indicating that this variable

Table 5 - Summary of comparisons between observed and predicted values and respective P-values within parentheses

\begin{tabular}{lcccc}
\hline Variables & \multicolumn{3}{c}{ Tests } \\
\cline { 2 - 5 } & MB & CD & CCC & ICC \\
\hline Milk production, $\mathrm{kg} \mathrm{d}^{-1}$ & $-1.846(0.066)$ & 0.364 & $0.182(0.319)$ & $0.193(0.339)$ \\
MPL, g d ${ }^{-1}$ & $-100.015(0.036)$ & 0.372 & $0.224(0.202)$ & $0.242(0.235)$ \\
NEL, MJ d & $-27.176(0.001)$ & 0.059 & $0.043(0.549)$ & $0.055(0.531)$ \\
DM intake, $\mathrm{kg} \mathrm{d}^{-1}$ & $-0.201(0.800)$ & 6.171 & $0.153(0.329)$ & $0.144(0.335)$ \\
\hline
\end{tabular}

MB - Mean bias; CD - coefficient of determination of the model; CCC - concordance correlation coefficient; ICC - intraclass correlation coefficient.

MPL - metabolizable protein for lactation; NEL - net energy for lactation; DM - dry matter. 
was independent of the adopted model. Nevertheless, the estimates of coefficient of determination, concordance correlation coefficient and intraclass correlation coefficient indicated low precision of the model predictions (Table 5).

The observed and predicted values were compared by robust regression, which showed an overestimation of the model predictions (Figure 2). The predictions of milk production were, on average, $18 \%$ higher than the observations (Figure 2A). The observed and predicted values of dry matter intake (Figure 2B) were highly correlated; thus, the model can be considered accurate, but not precise. In Figure 2C, the bias of the model in predicting $\mathrm{NE}_{\mathrm{L}}$ is evident, as the regression shows a different slope from the unit line. A higher proportion of points below the 1:1 line illustrates the overestimation of the predicted values (Figure 2C). The same overestimation was observed for $\mathrm{MP}_{\mathrm{L}}$ estimates (Figure 2D).

Assuming exact estimates by the model, the $\mathrm{NE}_{\mathrm{t}}$ intake was $33.2 \%$ higher than the $\mathrm{NE}_{\mathrm{t}}$ requirement for producing $13.7 \mathrm{~kg} \mathrm{~d}^{-1}$ of milk (Figure 3A). The energy obtained from forage and concentrate intake was enough to supply the production potential of the animals. This result indicates that the efficiency of utilization of the dietary energy was low, most likely because of an energy:protein imbalance.

On average, the consumed metabolizable protein matched the protein requirement of the lactating cows
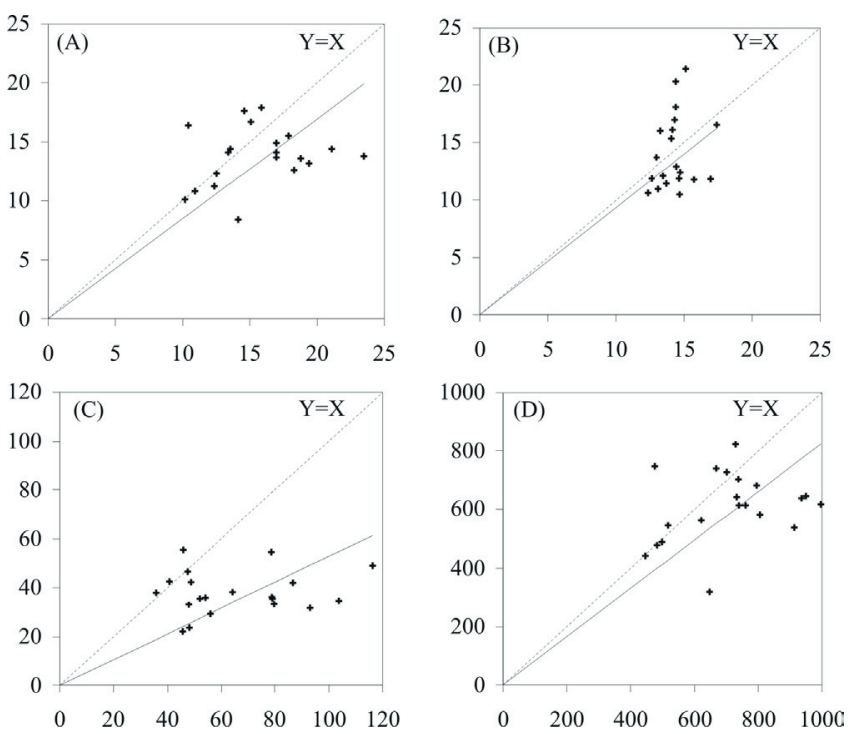

Robust estimations of the inclinations are $0.8472 \pm 0.0487(\mathrm{P}<0.001)$ for panel (A), $0.9323 \pm 0.0516(\mathrm{P}<0.001)$ for panel $(\mathrm{B}), 0.5275 \pm 0.0466(\mathrm{P}<0.001)$ for panel $(\mathrm{C})$, and $0.8261 \pm 0.0424(\mathrm{P}<0.001)$ for panel $(\mathrm{D})$.

Figure 2 - Comparisons between observed (Y axis) and predicted (X axis) values, related to the following variables: daily milk production $\left(\mathrm{kg} \mathrm{d}^{-1}\right.$, panel $\left.\mathrm{A}\right)$, dry matter intake $\left(\mathrm{kg} \mathrm{d}^{-1}\right.$, panel B), net energy for lactation $\left(\mathrm{kg} \mathrm{d}^{-1}\right.$, panel C) and metabolizable protein for lactation $\left(\mathrm{kg} \mathrm{d}^{-1}\right.$, panel D). during the experiment (Figure 3B). According to the model predictions, metabolizable protein was the first limiting nutrient. In this case, the $\mathrm{NE}_{t}$ surplus (Figure $3 \mathrm{~A}$ ) should have resulted in an increase in both body weight and body condition score. However, these effects were not evaluated because body weight and body condition score measurements are not sufficiently sensitive for short experimental periods.
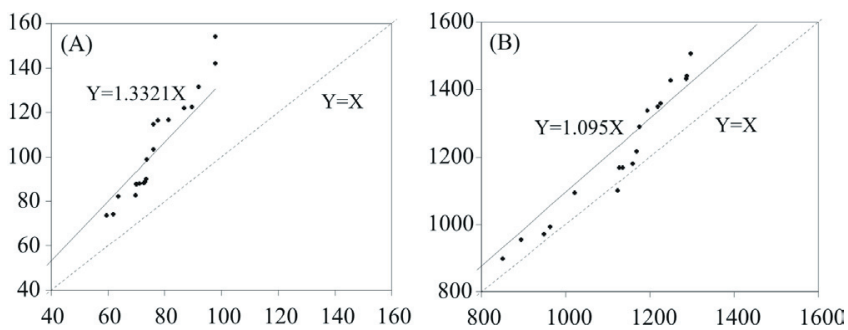

Figure 3 - Values supplied by the diet (Y) and required by the animal $(\mathrm{X})$ in total net energy for maintenance and production ( $\mathrm{NE}_{\mathrm{t}}, \mathrm{MJ} \mathrm{d}^{-1}$; panel $\mathrm{A}$ ) and in metabolizable protein for maintenance and production $\left(\mathrm{MP}_{\mathrm{t}}, \mathrm{g} \mathrm{d}^{-1}\right.$; panel B).

\section{Conclusions}

Tanzania grass has potential as forage for milk production in a rotational grazing system managed with three days of grazing and a thirty-day resting period. Because of a tendency toward overestimation of metabolizable protein and energy values, the model used in this study needs adjustments to enhance the accuracy and precision of predictions.

\section{Acknowledgments}

This research was partially supported by Fundação de Amparo à Pesquisa do Estado de Minas Gerais - FAPEMIG, and by Fundação Carlos Chagas Filho de Amparo à Pesquisa do Estado do Rio de Janeiro, process number E-26/110.231/2011.

\section{References}

Agricultural Food and Research Council. 1993. Energy and protein requirements of ruminants. $\mathrm{CAB}$ International, Wallingford, Oxford.

AOAC - Association of Official Analytical Chemists. 1990. Official methods of analysis. 15th ed. AOAC, Arlington, VA.

Balsalobre, M. A. A.; Corsi, M.; Santos, P. M.; Vieira, I. and Cárdenas, R. R. 2003. Composição química e fracionamento do nitrogênio e dos carboidratos do capim-Tanzânia irrigado sob três níveis de resíduo pós-pastejo. Revista Brasileira de Zootecnia 32:519-528. 
Barbosa, R. A. and Euclides, V. P. B. 1997. Valores nutritivos de três ecotipos de "Panicum maximum". p.53-55. In: Reunião Anual da Sociedade Brasileira de Zootecnia. Sociedade Brasileira de Zootecnia, Juiz de Fora.

Beuvink, J. M. W. and Spoelstra, S. F. 1992. Interactions between substrate, fermentation end-products, buffering systems and gas production upon fermentation of different carbohydrates by mixed rumen microorganisms in vitro. Applyied Microbiology and Biotechnology 37:505-509.

Bishop, J. P. and Froseth, J. A. 1970. Improved techniques in esophageal fistulization of sheep. American Journal of Veterinary Research 31:1505-1507.

Buxton, D. R. and Redfearn, D. D. 1997. Plant limitatons to fiber digestion and utilization. Journal of Nutrition 127:814S-818S.

Chambela Neto, A.; Fernandes, A. M.; Deresz, F.; Fontes, C. A. A. and Vieira, R. A. M. 2008. Composição químico-bromatológica e digestibilidade de três gramíneas tropicais em Minas Gerais. Archivos de Zootecnia 57:357-360.

Clipes, R. C.; Silva, J. F. C.; Detmann, E. and Vásquez, H. M. 2006. Composição químico-bromatológica da forragem durante o período de ocupação em pastagens de capim-elefante (Pennisetum purpureum, Schum) e capim-mombaça (Panicum maximum, Jacq) sob manejo rotacionado. Arquivo Brasileiro de Medicina Veterinária e Zootecnia 58:868-876.

Cochran, W. G. and Cox, G. M. 1954. Experimental design. Wiley, New York.

Favoreto, M. G.; Deresz, F.; Fernandes, A. M.; Vieira, R. A. M. and Fontes, C. A. A. 2008. Avaliação nutricional da grama-estrela cv. Africana para vacas leiteiras em condições de pastejo. Revista Brasileira de Zootecnia 37:319-327.

Fisher, M. J.; Rao, L. M.; Thomas, R. J. and Lascano, C. E. 1996. Grassland in the well-watered tropical lowlands. p.393-425. In: The ecology and management of grazing systems. J. Hodgson, J. and Illius, A.W., eds. CAB International, Wallingford, Oxford.

Fox, D. G.; Tedeschi, L. O.; Tylutki, T. P.; Russell, J. B.; Van Amburgh, M. E.; Chase, L. E.; Pell, A. N. and Overton, T. R. 2004. The Cornell Net Carbohydrate and Protein System model for evaluating herd nutrition and nutrient excretion. Animal Feed Science Technology 112:29-78.

Gerdes, L.; Werner, J. C.; Colozza, M. T.; Possenti, R. A. and Schammass, E. A. 2000. Avaliação de características de valor nutritivo das gramíneas forrageiras Marandu, Setária e Tanzânia nas estações do ano. Revista Brasileira de Zootecnia 29:955-963.

Goering, H. K. and Van Soest, P. J. 1970. Forage fiber analysis. Agricultural handbook No. 379. U.S.D.A, Washington, D.C.

Gomide, C. A. M. and Gomide, J. A. 2001. The duration of regrowth period and the structural traits in a rotationally grazed Panicum sward. p.850-851. In: Proceedings of the 19th International Grassland Congress, São Pedro. FEALQ, Piracicaba.

Hodgson, J.; Bircham, J. S.; Grant, S. A. and King, J. 1981. The influence of cutting and grazing management on herbage growth and utilization. p.51-62. In: Plant physiology and herbage production. Wright, C. E., ed. Massey University: British Grassland Society, Palmerston North.

Hodgson, J. 1985. The significance of sward characteristics in the management of temperate sown pastures. p.63-67. In: Proceedings of the 15th International Grassland Congress, Japan. Japanese Society of Grassland Science; Science Council of Japan, Kyoto.

Jardim, J. G.; Vieira, R. A. M.; Fernandes, A. M.; Araujo, R. P.; Glória, L. S.; Rohem Júnior, N. M.; Rocha, N. S. and Abreu, M. L. C. 2013. Application of a nonlinear optimization tool to balance diets with constant metabolizability. Livestock Science 158:106-117.

Lechner-Doll, M.; Kaske, M. and Engelhardt, W. V. 1991. Factors affecting the mean retention time of particles in the forestomach of ruminants and camelids. p.455-482. In: Physiological aspects of digestion and metabolism in ruminants: Proceedings of the 7th International Symposium on Ruminant Physiology. Tsuda, T.; Sasaki, Y. and Kawashima, R., eds. Academic Press, San Diego.

Lemaire, G. and Chapman, D. 1996. Tissue flows in grazed plant communities. p.3-36. In: The ecology and management of grazing systems. Hodgson, J. and Iillius, A.W., eds. Cab International, Wallingford, Oxford.

Lima, M. L. P.; Berchielli, T. T.; Nogueira, J. R. Ruggieri, A. C.; Aroeira, L. J. M.; Salman, A. K. A. and Soares, J. P. G. 2001. Estimativa do consumo voluntário do capim-Tanzânia (Panicum maximum, Jacq. cv. Tanzânia) por vacas em lactação sob pastejo rotacionado. Revista Brasileira de Zootecnia 30:1919-1924.

Lopes, F. C. F. 2002. Taxa de passagem, digestibilidade in situ, consumo, composição química e disponibilidade de capim-elefante (Pennisetum purpureum, Schumack) pastejado por vacas mestiças Holandês x Zebu em lactação. Tese (D.Sc.). Universidade Federal de Minas Gerais, Belo Horizonte.

Lucas, H. L. and Smart, W. W. G. 1959. Chemical composition and the digestibility of forages. p.23-26. In: Proceedings of the 16th Pasture and Crop Improvement Conference. Mississipi State University, Mississipi.

Malafaia, P. A. M.; Valadares Filho, S. C. and Vieira, R. A. M. 1999. Kinetic parameters of ruminal degradation estimated with a non-automated system to measure gas production. Livestock Production Science 58:65-73.

Matis, J.H. 1972. Gamma time-dependency in Baxter's Compartmental Model. Biometrics 28:597-602.

Matis, J. H.; Wehrly, T. E. and Ellis, W.C. 1989. Some generalized stochastic compartment models for digesta flow. Biometrics 45:703-720.

Mott, G. O. 1960. Grazing pressure and the measurement of pasture production. p.606-611. In: Proceedings of the 8th International Grassland Congress. University of Reading, Reading.

Nelson, T. 2011. The Grass leaf development gradient as a platform for a systems undestanding of the anatomical specialization of $\mathrm{C} 4$ leaves. Journal of Experimental Botany 62:3039-3048.

NRC - National Research Council. 2001. Nutrient requirements of dairy cattle. 7th rev. ed. National Academy Press, Washington, DC.

Pond, K. R.; Ellis, W. C.; Matis, J. H.; Ferreiro, H. M. and Sutton, J. D. 1988. Compartment models for estimating attributes of digesta flow in cattle. British Journal of Nutrition 60:571-595.

Russel, J. B.; O’Connor, J. D.; Fox, D. G.; Van Soest, P. J. and Sniffen, C. J. 1992. A net carbohydrate and protein system for evaluating cattle diets: Ruminal fermentation. Journal of Animal Science 70:3551-3561.

Schofield, P. and Pell, A. N. 1995. Measurement and kinect analysis of the neutral detergent-soluble carbohydrate fraction of legumes and grasses. Journal of Animal Science 73:3455-3463.

Silva, A. G.; França, A. F. S.; Miyagi, E. S.; Mello, S. Q. S.; Ferreira, J. L. and Carvalho, E. R. 2009. Frações proteicas do capim-mombaça submetido a doses de nitrogênio em duas alturas de corte. Arquivo Brasileiro de Medicina Veteterinária e Zootecnia 61:1148-1155.

Simon, B. K. and Jacobs, S.W. 2003. Megathyrsus, a new generic name for Panicum subgenus Megathyrsus. Austrabaileya 6:571-574.

Sniffen, C. J.; O'Conor, J. D.; Van Soest, P. J.; Fox, D. G. and Russel, J. B. 1992. A net carboydrate and protein system for evaluing cattle diets: II Carbohydrate and protein availability. Journal of Animal Science 70:3562-3577.

Souza, H. M. 2006. Modelagem matemática e proposta de resolução do problema da dieta alimentar para gado bovino de corte. Dissertação (MSc.). Universidade Federal do Rio de Janeiro, Rio de Janeiro.

Tedeschi, L. O.; Fox, D. G. and Guiroy, P. J. 2004. A decision support system to improve individual cattle management. 1. A 
mechanistic, dynamic model for animal growth. Agricultural Systems 79:171-204.

Tedeschi, L. O. 2006. Assessment of the adequacy of mathematical models. Agricultural Systems 89:225-247.

Tedeschi, L. O.; Chalupa, W.; Janczewski, E.; Fox, D. G.; Sniffen, C.; Munson, R.; Kononoff, P. J. and Boston, R. 2008. Evaluation and application of the CPM dairy nutrition model. Journal of Agricultural Science 146:171-182.

Udén, P.; Colucci, P. E. and Van Soest, P. J. 1980. Investigation of chromium, cerium and cobalt as markers in digesta. Rate of passage studies. Journal of the Science of Food and Agriculture 31:625-632.

Van Soest, P. J.; Robertson, J. B. and Lewis, B. A. 1991. Methods for dietary fiber, neutral detergent fiber, and nonstarch polyssacharides in relation to animal nutrition. Journal of Dairy Science 74:3583-3597.

Van Soest, P. J. 1994. Nutritional ecology of the ruminant. 2nd ed. Cornell University Press, Ithaca, NY.
Vieira, R. A. M.; Pereira, J. C.; Malafaia, P. A. M.; Queiroz, A. C. and Gonçalves, A. L. 2000. Fracionamento dos carboidratos e cinética de degradação in vitro da fibra em detergente neutro da extrusa de bovinos a pasto. Revista Brasileira de Zootecnia 29:889-897.

Vieira, R. A. M.; Tedeschi, L. O. and Cannas, A. 2008a. A generalized compartmental model to estimate the fibre mass in the ruminoreticulum: 1. Estimating parameter of digestion. Journal of Theoretical Biology 255:345-356.

Vieira, R. A. M.; Tedeschi, L. O. and Cannas, A. 2008b. A generalized compartmental model to estimate the fibre mass in the ruminoreticulum: 2. Integrating digestion and passage. Journal of Theoretical Biology 255:357-368.

Waters, C. J.; Kitcherside, M. A. and Webster, A. J. F. 1992. Problems associated with estimating the digestibility of undergrated dietary nitrogen from acid detergent insoluble nitrogen. Animal Feed Science Technology 39:279-291.

Wilson, J. R. and Mertens, D. R. 1995. Cell-wall accessibility and cell structure limitations to microbial digestion of forage. Crop Science $35: 251-259$ 